\title{
Teachers' Oral Feedback in EFL Classroom Interaction (A Descriptive Study of Senior High School in Indonesia)
}

\author{
Erfiani Irawan \\ erfianiirawan@gmail.com \\ Kisman Salija \\ kismansalija@unm.ac.id
}

State University of Makassar, Indonesia

\begin{abstract}
This research aimed to identify types and ways of oral feedback used by teachers in EFL classroom interaction based on the theory of Tunstall \& Gipss (1996), Lyster \& Ranta (1997), Cullen (2002), and Mackiewicz \& Thompson (2013). This research also investigated teachers' reasons for using oral feedback and students' perceptions of oral feedback used by teachers in EFL classroom interaction. This research was conducted at Senior high school in Indonesia. The researcher applied descriptive qualitative research method. The subjects of this research were 2 English teachers and 12 students. All of them were chosen by using purposive sampling technique. The instruments of this research were audio recording, field notes, and interview. The result of this research showed that the teachers used 5 types of oral feedback, namely evaluative feedback, corrective feedback, descriptive feedback, interactional feedback, and motivational feedback. The teachers used oral feedback through providing evaluative statements to students' work or performance, indicating and correcting students' errors explicitly or implicitly, informing students' achievement and the improvement strategies of learning, clarifying and embellishing some ideas on students' responses, and providing motivational statements to students. The teachers employed oral feedback because of teachers' responsibility and obligation to provide it, the effective and efficient feedback mode, the utility of oral feedback, positive effect to students, and consequences of none of oral feedback. Mostly, the students perceived positively to oral feedback. Some students found felt sensitive to oral feedback. Nevertheless, they still realized to its positive effect on the result of their work or performance.
\end{abstract}

Keyword: Teachers' oral feedback, EFL classroom interaction

\section{INTRODUCTION}

Teacher's feedback, one of the features of teacher talk, has taken an essential and inevitable part to create communication in EFL classroom. Feedback is conceptualized as information about one's performance or understanding delivered by an agent (Hattie \& Timperley, 2007). In teaching and learning schemes, feedback is prominently introduced by Sinclair \& Coulthard (1975). It comes from the idea of I-R-F exchange structure where ' $I$ ' is the teacher initiation to pose a question, ' $R$ ' represents students' performance or work, and ' $F$ ' is the teacher feedback or follow up to students' performance or work. Feedback mode can be spoken, written, and non-verbal. As feedback in spoken mode (oral feedback) emerges frequently in EFL classroom, it becomes the focus of this study. Teachers' oral feedback is required. The teaching and learning process can occur with it. The feedback content can support students' good performance and achievement in 
English learning. This brings to a noteworthy comprehension that oral feedback can contribute to the language learning (Ellis, 2009).

Many studies on teachers' oral feedback in ESL/EFL classroom interaction have been conducted in western countries (Noor, et al., 2010 in Malaysia; Pfanner, 2015 in Michigan; Ran \& Danli, 2016 in China). Other studies were conducted in Indonesia (Maolida, 2013; Syam, 2015; Permatasari, 2016). An example of study from western countries was by Ran \& Danli (2016) who found that evaluative feedback, corrective feedback, and interactive feedback were utilized by the teachers in EFL classroom. Maolida (2013) found that the teacher used both positive feedback and corrective feedback in ESL classroom.

Every EFL teacher possesses their own choices of oral feedback. Pinto \& Santos (2008) viewed that the way teachers' oral feedback appears is diverse. Many types of oral feedback are used in different situations with different ways. The teachers' reasons for oral feedback use are unpredictable on account of the inconsistency of feedback provision. Ikeda (2010) argued that it is not so simple for teachers to provide it in consideration of students' feeling. Even though oral feedback is necessary for learning, Black \& William (1998) noted that teachers still have less reflective action to their ways of assessment. This case brings to the idea for the teachers to do self-assessment in delivering oral feedback. Then, understanding how students perceive teachers' oral feedback is important because it can help teachers to develop the practices of reflective and effective feedback (Lee, 2008).

This paper attempts to identify types and ways of oral feedback used by the teachers. It is also to investigate teachers' reasons for using oral feedback and students' perception of teachers' oral feedback in EFL classroom interaction. Findings in this study are valuable to be considered by teachers in providing effective oral feedback.

\section{REVIEW OF RELATED LITERATURE Definition of feedback}

Kluger \& Denisi (1996) defined feedback as information provided to someone referring to his or her performance. Some instances of feedback action are mentioned by Hattie \& Timperley (2007). They are teacher's correction to students' mistakes, a peer's assistance to a partner, parents' motivation to their children, a reader's clarification to the idea from a book, and a student's corrective and evaluation answer. It is concluded that feedback is the information provided by the one who perceives someone's performance.

\section{Types of teachers' oral feedback}

There are some types of teachers' oral feedback. They are evaluative feedback, corrective feedback, descriptive feedback, interactional feedback, and motivational feedback. Evaluative feedback regards the form of judgment on students' performance or work (Tunstall \& Gipps, 1996). Tunstall \& Gipps (1996) classified ways of evaluative feedback into rewarding, punishing, approving, and disapproving. Corrective feedback is a response given to a learner's error (Ellis, 2006). Lyster \& Ranta (1997) investigated corrective feedback into recast, explicit correction, elicitation, metalinguistic feedback, and repetition. 
According to Hargreaves, McCallum \& Gipps (2000), descriptive feedback is the specific information about students' strength and weakness and improvement strategies. It is classified into specifying attainment and improvement and constructing achievement and constructing the way forward (Tunstall \& Gipps, 1996). Interactional feedback has a comment contributing to enhance students' language production (Garcia, 2005). Cullen (2002) categorized interactional feedback into reformulation, elaboration, comment, and repetition. According to Mackiewicz \& Thompson (2013), motivational feedback aims to encourage students in learning. Then, Mackiewicz \& Thompson (2013) described five ways of motivational feedback into praise, statements of encouragement or optimism, demonstrations of concern for students, expressions of sympathy and empathy, and reinforcement of students' feeling of ownership and control.

\section{Students' perceptions of teachers' oral feedback}

A perception of students about teachers' oral feedback relates to the way they think, interpret, understand, or notice teachers' oral feedback within their senses. Studies on students' perception of teachers' oral feedback can provide information for teachers to know how to give oral feedback effectively based on their view (Cowie, 2005; Gamlem \& Smith, 2013). Cowie' study (2005) showed the use of oral feedback which can impact students' feeling positively and negatively. Then, Gamlem \& Smith (2013) contended that students' experience and perspective of teachers' oral feedback can contribute to the teaching practice. They explained that it can assist teachers to understand the needs of students to feedback and do the adaptation of feedback to fulfil their needs.

\section{METHOD}

The method of this research was a descriptive qualitative method. The subjects of the research were 2 English teachers and 12 students of one of senior high schools in Indonesia. Purposive sampling technique was applied to choose them. The teachers were chosen because they actively delivered oral feedback to students. Those teachers have teaching experience for more than ten years. The selection of students was based on their high academic proficiency and engagement.

To collect the data of this research, three kinds of instrument were used namely, audio recording, field notes, and semi-structured interview. By activity, the researcher observed and recorded the teaching and learning process. The observation was conducted through making field notes. Afterwards, the teachers and students were interviewed about the use of oral feedback in EFL classroom interaction. In process of data analysis, it was conducted by using the interactive model of Miles \& Huberman (2014). The data from audio recording were transcribed. The result of observation and interview were analyzed. Afterwards, the process of coding was applied and categorized based on the research questions addressed. The next process was displaying the data in descriptive explanation and table.

\section{FINDINGS AND DISCUSSION}

\section{Types of oral feedback used by teachers in EFL classroom interaction}

From the analysis of data, the researcher found five types of oral feedback used by the teachers in EFL classroom. They were evaluative feedback and descriptive feedback from the theory of Tunstall \& Gipss (1996), corrective feedback from the theory of Lyster \& 
Ranta (1997), interactional feedback from the theory of Cullen (2002), and motivational feedback from the theory of Mackiewicz \& Thompson (2013). The detailed findings are presented below.

\section{Evaluative feedback}

\section{Extract 1: Asking the actor in a story}

Teacher B assigned the students to read the narrative text carefully and queried them to find the main character of the story.

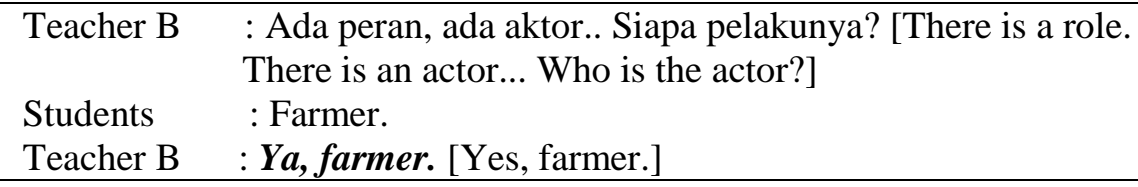

Extract 1 reveals that teacher B responded the students' answer by exerting evaluative feedback. The students replied his question by saying farmer altogether. In this exchange, the teacher said $\mathbf{Y a}$, farmer [Yes, farmer] to the answer expressed by them. This pattern can be seen as acknowledging what they had said. Tunstall \& Gipps (1996) asserted that evaluative feedback is judgment indicating teacher approval to students' work.

\section{Corrective feedback}

\section{Extract 2: Differentiating the word add and pour}

Teacher A had the students arrange the pictures into the right order and describe them. The topic of pictures was the direction of making a cup of tea.

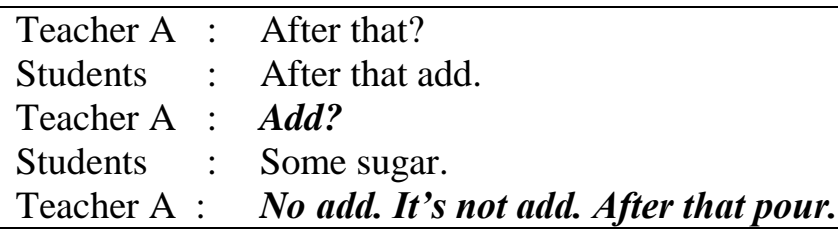

Corrective feedback was identified in extract 2 above. When the students answered the question, teacher A responded it with the partial repetition of their answer by uttering $\boldsymbol{A} \boldsymbol{d} \boldsymbol{d}$ ? to point the error implicitly. Then, the students continued their answers. This case made him explicitly tell the error by uttering No add. It's not add. Then, he reformulated students' response with the correct answer by saying After that pour. In Ellis' notion (2006), corrective feedback relates to how the teacher response to an error made by students.

\section{Descriptive feedback}

\section{Extract 3: Telling student's achievement}

In this situation, teacher B explained narrative text in detail. Then, he asked them the definition of narrative text. 


$\begin{array}{lll}\text { Teacher B } & : & \text { The story in the? } \\ \text { Students } & : & \text { Past. } \\ \text { Teacher B } & : & \text { Past. } \\ \text { Students } & : & \text { In the past. } \\ \text { Teacher B } & : & \text { Iyyaaa, I think you have done it. [Yes, I think you have done it.] } \\ \text { Student } & : & \text { In the past. } \\ \text { Teacher B } & : & \text { Yeah. You you have.. talked in front of the class about the story. } \\ & & \text { Yeah. Everybody has already.. has done it well. Iyah [yes] but and } \\ & \text { most of the students ever performed.. in front of the class.= }\end{array}$

In extract 3, teacher B informed the students' good achievement regarding their performance in telling the narrative story in front of the class. He provided descriptive feedback by saying Yeah. Everybody has already.. has done it well. It signifies that the students had achieved the aim of learning at the previous meeting. According to Tunstall \& Gipps (1996), descriptive feedback is provided by connecting among the learning goals, criteria of learning success, and students' accomplishment.

\section{Interactional feedback}

\section{Extract 4: Giving solution}

Teacher A asked the students to find a solution about having a teenage son who always hangs out every night by a family car.

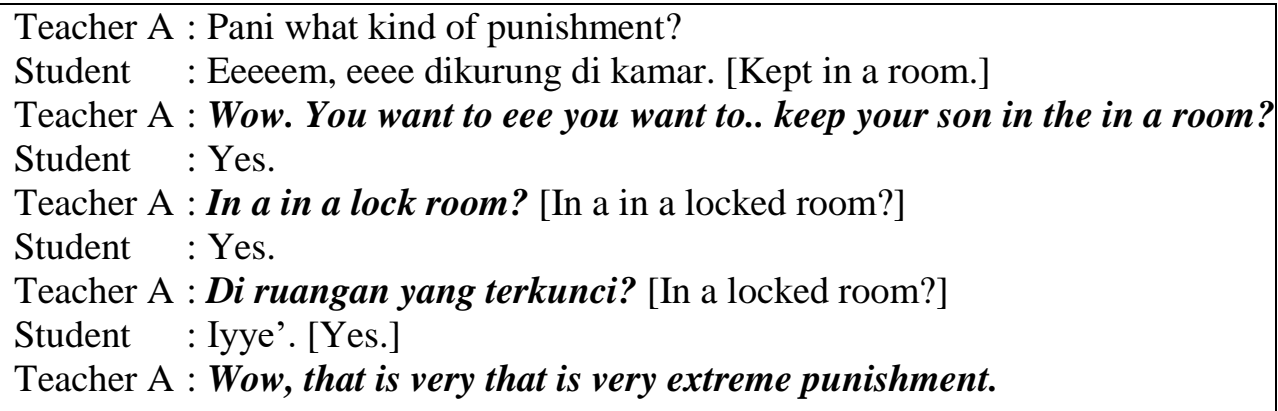

In extract 4, the student offered the solution by keeping this teenager in a locked room. Responding to the student's answer, teacher A used interactional feedback. Firstly, he expressed his surprise by saying Wow. Then, he showed his intention to encourage her to talk by saying You want to eee you want to.. keep your son in the in a room? The student confidently said yes. Then, teacher A wanted her to tell the reason but she only responded by saying Iyye' [Yes]. Spontaneously, he commented it by verbalizing Wow, that is very that is very extreme punishment. Garcia (2005) on her study noting that interactional feedback focuses on the content which is not evaluative and corrective.

\section{Motivational feedback}

\section{Extract 5: Telling a life story}

At the end of the class, teacher B wanted one of students to tell the story of their life in front of the class. 


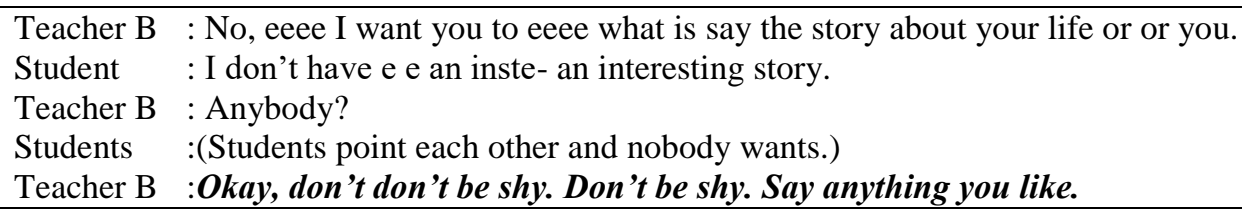

Extract 5 illustrates the student who did not have any interesting story. When teacher B said Anybody?, every student pointed each other and called their friends' name. Facing this situation, teacher B provided statements of encouragement or optimism to them. The utterance was Okay, don't don't be shy. Don't be shy. In addition, he demonstrated his concern for them by uttering Say anything you like to create the comfortable situation in their learning process so it could foster them to share their story in front of the class. Mackiewicz \& Thompson (2013) mentioned that motivational feedback is the teacher's notice to increase students' self-confidence and optimism.

\section{Teachers' ways of using oral feedback in EFL classroom interaction}

The researcher explained teachers' ways of using oral feedback through discussing the ways of every type of oral feedback undertaken by the teachers in EFL classroom interaction. The findings are displayed into the following table:

Table 1 Data Display of Teachers' Ways of Using Oral Feedback

\begin{tabular}{|c|c|c|}
\hline $\begin{array}{l}\text { Types of Oral } \\
\text { Feedback }\end{array}$ & $\begin{array}{l}\text { Ways of Oral } \\
\text { Feedback }\end{array}$ & Teacher Feedback \\
\hline \multirow{3}{*}{$\begin{array}{l}\text { Evaluative } \\
\text { feedback }\end{array}$} & Approving & $\begin{array}{l}\text { Were, okay. Good; Okay, right!; Iyya } \\
\text { [yes] }\end{array}$ \\
\hline & Disapproving & $\begin{array}{l}\text { [Yeah], you don't. You, you don't ask } \\
\text { the expression of asking and giving } \\
\text { opinion. You are not giving me.. the } \\
\text { example.. of asking, eee no opinion. I } \\
\text { don't say opinion. [[Sorry]]. }\end{array}$ \\
\hline & Rewarding & Clap hands. \\
\hline \multirow{7}{*}{$\begin{array}{l}\text { Corrective } \\
\text { feedback }\end{array}$} & Recast & Evaluation_(/I,voellu'eIfən/)? \\
\hline & Explicit correction & $\begin{array}{l}\text { You should. Don't use must. Okay? } \\
\text { Because e giving advice, we avoid to use } \\
\text { must... }\end{array}$ \\
\hline & Elicitation & $\begin{array}{l}\text { Iya [yes], I felt..?; But, why... there is } s \\
\text { here? }\end{array}$ \\
\hline & Clarification request & Ha?; Yah? [Yes?]; Apa? [What?]; Ah? \\
\hline & $\begin{array}{l}\text { Metalinguistic } \\
\text { feedback }\end{array}$ & $\begin{array}{l}\text { Yang sering-sering muncul di dalam teks } \\
\text { itu. [It often appears on the text.] }\end{array}$ \\
\hline & Repetition & Okay, he doesn't ever leave you. \\
\hline & Praise \& correction & $\begin{array}{l}\text { Okay, it is good but there is something } \\
\text { to be corrected. }\end{array}$ \\
\hline $\begin{array}{l}\text { Descriptive } \\
\text { feedback }\end{array}$ & Specifying attainment & $\begin{array}{l}\text { And you know also the.. the what is.. eee } \\
\text { the.. language features. Language } \\
\text { features itu maksudnya unsur } \\
\text { kebahasaan. For example, uses simple } \\
\text { present tense, right? Ahaa, using a } \\
\text { action verb or imperative kata-kata }\end{array}$ \\
\hline
\end{tabular}


perintah. Yes? Using a a sentence connector for example, first, then, and also ee some adverbial. Verb berapa? Adverb yah? Adverbial. Now, ee so ee the goal the goal of the.. the curriculum is accomplished to you. [And you know also the language feature. Language features mean language elements. For example, uses simple present tense, right? Ahaa, using an action verb or imperative sentence. Yes? Using a sentence connector for example, first, then, and also some adverbs. What verb? Adverb right? Adverb. Now, the goal of the curriculum is accomplished to you.]

Maksudnya begini kalau kita. if you have done something, recheck. Kalau kau sudah kerja sesuatu, periksa kembali ke ru.. rumus. Betul dak urutannya ini. Dih? Mungkin kau dak

Specifying improvement periksa karena sudah semangat. Ah, benarmi ini pokoknya benarmi. [I mean if we.. if you have done something, recheck. If you have done something, recheck the pattern. Is it true? Okay? Maybe you don't check because you have got spirit. Ah, this is true. Importantly, this is true.]

\begin{tabular}{|c|c|c|}
\hline \multirow{6}{*}{$\begin{array}{l}\text { Interactional } \\
\text { feedback }\end{array}$} & Reformulation & Yaaa [yes] we may not.. take. \\
\hline & Elaboration & $\begin{array}{l}\text { Aaa you didn't sleep well maybe } \\
\text { because of activities or homework or } \\
\text { maybe chatting via telephone or maybe } \\
\text { browsing internet et cetera. So, many } \\
\text { reason[s] why people didn't sleep well. }\end{array}$ \\
\hline & Comment & $\begin{array}{l}\text { I myself if I.. if I go to bed under twelve, } \\
\text { it means that I go to bed early. }\end{array}$ \\
\hline & Repetition & Don't be the greedy one. \\
\hline & Questioning & $\begin{array}{l}\text { What about.. e if you go to bed ee up up } \\
\text { eleven? Di atasnya jam.. sebelas eleven } \\
\text { [above eleven?]. Ee do you think that } \\
\text { you go to bed early or late? }\end{array}$ \\
\hline & Giving help & $\begin{array}{l}\text { Saya hanya ingin akan menjelaskan } \\
\text { tentang.. [I want to explain about..] }\end{array}$ \\
\hline \multirow{3}{*}{$\begin{array}{l}\text { Motivational } \\
\text { feedback }\end{array}$} & Praise & Because it is very good point. \\
\hline & $\begin{array}{l}\text { Statements of } \\
\text { encouragement/ } \\
\text { Optimism }\end{array}$ & Okay, don't don't be shy. Don't be shy. \\
\hline & $\begin{array}{l}\text { Expression of } \\
\text { sympathy and } \\
\text { empathy }\end{array}$ & $\begin{array}{l}\text { Okay, you can write down your your } \\
\text { point on the whiteboard and then you ee } \\
\text { so we-- we understand. We can eeee.. }\end{array}$ \\
\hline
\end{tabular}


ELT Worldwide Vol. 4 No. 2 (2017)

Irawan \& Salija: Teachers' Oral Feedback in Classroom ...

\begin{tabular}{ll}
\hline $\begin{array}{l}\text { Demonstrations of } \\
\text { concern for students }\end{array}$ & we try to understand what is your point. \\
\hline $\begin{array}{l}\text { Reinforcement of } \\
\text { students' feeling of } \\
\text { ownership }\end{array}$ & $\begin{array}{l}\text { Hoo, you're afraid to make mistake. But } \\
\text { different, different. }\end{array}$ \\
\hline Expectancy & $\begin{array}{l}\text { I hope other.. participants or groups } \\
\text { will be.. active again. }\end{array}$ \\
\hline Giving help & $\begin{array}{l}\text { I am going to help you. Saya akan bantu } \\
\text { [I am going to help you. I am going to } \\
\text { help you to express your idea. }\end{array}$ \\
\end{tabular}

The findings show the various ways of oral feedback in EFL classroom interaction. The first one is evaluative feedback ways. In providing it, the teachers approved the correct answer by saying 'good', 'okay, right', disapproved the incorrect answer by saying 'no', 'don't say...', and rewarded the students' correct answer with the gift of applause. These ways are covered in Tunstall \& Gipps' theory (1996). Evaluative feedback is employed to accept students' answer (Al Fahdi, 2006; Ran \& Danli, 2016). As Tunstall \& Gipps (1996) emphasized the use of disapproval on conative aspect, the finding indicated that this could be used in cognitive aspect. Voerman, et al. (2012) contended that feedback can include disapproving statements to students' work or comprehension.

Corrective feedback is employed by the teachers through some ways. They used recast by giving restatement to incorrect response. In explicit correction, the teachers pointed an error and reformulated it with the correct answer. Besides, the teachers utilized elicitation for completion and Wh-question. When there was teachers' misunderstanding or erroneous response, they used clarification request. Another way is metalinguistic feedback. The provision of information, comment, and yes-no question is used to indicate the error. They also repeated the incorrect response. Those ways were mentioned by Lyter \& Ranta (1997). In interview result, the use of praise and correction is found as a new way. The teachers praised the students firstly. Then, they pointed and corrected the error. Findings from this study indicate that the teachers employed descriptive feedback through informing students' achievement by correlating it with the goal of curriculum. This refers to specifying attainment. Hargreaves, et al.'s study (2000) found the use of specifying attainment to tell what the students had attained and not attained on their work. The teachers also provided learning strategies and suggestions to the students for better learning result. It is recognized as specifying improvement. Tuntall \& Gipps (1996) formulated specifying attainment and improvement for descriptive feedback.

The ways of interactional feedback covered Cullen's theory (2002). They are reformulating students' response, giving elaboration, commenting, and repeating their response. These ways were found to trigger students to talk further. Garcia's statement (2005) on her study noted interactional feedback which is neither evaluative nor corrective. In addition, questioning and giving assistance were found in this study. The use of questioning signified the teachers' intention to encourage students to give more explanation about their response. The teachers also provided assistance with the additional words so students can continue their talk. Specifically, other studies supported these findings, for instance: questioning (Tharawoot, 2009) and giving assistance (Richard \& Lockhart, 1996; Noor, et al., 2010; Ran \& Danli, 2016). These ways complete Cullen's classification (2002) of interactional feedback. 
In motivational feedback, the teachers used praise and statements of encouragement or optimism. To show teachers' acceptance to what students will perform, demonstrations of concern for students were utilized. Another way is to express sympathy and empathy for the difficulty. Also, the teachers reinforced students' feeling of ownership and control to their work. These ways were covered on the theory from Mackiewicz \& Thompson (2013). The findings show two ways which are not mentioned on Mackiewicz \& Thompson's theory (2013). The teachers verbalized their expectancy to students for being active and showing the future work which is better than previous work. The teachers also articulated the expression of giving help to generate students' feeling of ease in doing task.

\section{Teachers' reasons for using oral feedback in EFL classroom interaction}

The findings from interview reveal that there are some reasons of the teachers to use oral feedback in EFL classroom interaction. The detailed findings are presented below:

Extract 6: The responsibility and obligation to give oral feedback

I think teachers should.. should.. teacher.. not should but must prepare feedback for students. As a responsibility as a teacher because teacher cannot just sit around. Teacher cannot sit around and then with no feedback. We cannot, we cannot let students to make mistake.. going on mistake, continuing mistake. We stop, we have to.. we have to stop them to make continuing mistake by giving them feedback.

According to teacher A, oral feedback is obliged for teachers to provide. It is to prevent students to make errors or mistakes continually. Cullen (2002) argued that feedback acts as the obligatory and unavoidable feature when the teacher initiates exchange in the classroom.

\section{Extract 7: Using oral feedback owing to its efficiency}

Saya gunakan umpan balik secara lisan yaa karena lebih efisien. Yaa kemudian lebih efektif dan tidak menggunakan waktu yang terlalu lama sehingga siswa langsung termotivasi yang mana yang benar dan yang mana yang salah. [I use feedback orally because it is more efficient. Then, it is more effective and not wasting our time too long so students are directly motivated to which one is true and which one is wrong.]

Teacher B argued that oral feedback is used because of its effective and efficient mode. The teacher can immediately and quickly inform the students about their performance or work, such as: the information of their mistakes. Brookhart (2008) stated that oral feedback can create an interaction between the teacher and students in the valuable short time of teaching.

\section{Extract 8: To build interactive communication}

Interactional feedback is very interesting way to give feedback because you know we as teachers should be not must be. Hah, I don't say must be. Should be more creative. Yes, creative to propose some topic of conversation. So, it is interpersonal. So, it should be in interactive communication. So, interactional feedback is focusing on how to to get students' attention and how to gain student... interaction in our class.

Teacher A utilized oral feedback because of its utility in teaching students. For instance: interactional feedback is functioned to draw students' attention and create interactive 
communication in EFL classroom. Acheson \& Gall (1980) claimed that to view the importance of feedback, it can be related to the techniques of oral feedback.

\section{Extract 9: Oral feedback is very educating}

In my experience teaching experience when I give them oral feedback, students [are] more active than written feedback because you know some teachers also only use.. written feedback but in my experience giving oral feedback is very very very.. is very very very.. educating. Iya [Yes], because they practice their listening and then we teacher practice our speaking.

Another reason is that oral feedback has the effect to make students more active in the classroom rather than written feedback. It is also very educating to help students to practice the target language. Students' competence and achievement can be improved through feedback (Tunstall \& Gipps, 1996).

\section{Extract 10: Making students lazy to study and do the task}

Konsekuensinya akibatnya barangkali berdampak kepada siswa sendiri. Yah, siswa bisa malas. Siswa tidak mau bekerja dan siswa malas melakukan untuk hal-hal yang diberikan, tugas yang diberikan. Dia anggap angin seperti biasa-biasa saja. [The consequence may impact on the student him/herself. Yes, the student can be lazy. The student does not want to work and the student is lazy to do things given to them, the task given to him/her. He/she thinks that it is an ordinary thing.]

The last reason deals with the consequences of none of oral feedback. Teacher A perceived that students can be lazy to study and do the task without oral feedback. They will underestimate every task given to them. Acheson \& Gall (1980) argued that it can cause bad learning habit which gradually makes them stop learning when there is no oral feedback.

\section{Students' perceptions of oral feedback used by teachers in EFL classroom interaction}

Findings reveal that oral feedback is much appreciated among students. Most of them perceived positively to oral feedback. Their perceptions are displayed on the following extracts.

\section{Extract 11: Feeling happy and proud}

Student I stated his perception about evaluative feedback.

Perasaanku itu sudah bagus. Seperti, saya senang mendapatkan yang seperti itu kak karena saya seperti bangga begitu. [I think it has been good. Like, I feel happy to get something like that miss because I feel proud to that one.]

Student B expressed his short statement.

\section{Extract 12: Repairing the work}

Kalau bilang no, perbaiki lagi. Tapi kadang juga bikin nyali ciut kalau bilang no. [If it is no, repair it again. But, sometimes it also makes us feel down if getting no.]

Extract 11-12 above showed how the students perceived evaluative feedback. In extract 11, student I expressed her happiness and pride after getting approval. In extract 12, student B thought that when teacher A said no, it was his time to repair his answer. 
However, he felt that disapproval made him feel not confident. It is also underlined in studies conducted by Cowie (2005) and Gamlem \& Smith (2013) stating that approval makes students happy and feels motivated for next work. Cowie (2005) also found that disapproval can lose students' motivation. Gamlem \& Smith (2013) argued that it can support and obstruct the learning.

Extract 13: Knowing the mistake

Student F conveyed her perception of corrective feedback.

Menurut saya bagus karena kita tahu salah kita dimana. Berarti kalau misalnya ada kesalahan saat membuat kalimat, kita pasti ingat disini biasanya salah, lalu kita sudah ingat, biasa dibenarkan. [In my view, it is good because we know where our mistake is. It means that if there is mistake when making sentence, we can remember where the mistake is, then we have remembered it, usually it is corrected.]

\section{Extract 14: Feeling down to the correction}

Student $\mathrm{H}$ told her perception of corrective feedback.

Perasaan saya, mungkin apa yah.. merasa mungkin berkecil hati karena jawaban yang diberikan ternyata salah tetapi karena sudah dikoreksi jadi tahu apa kesalahannya. [My feeling, maybe.. I feel down because the answer is wrong. But, because of the correction I can know where the mistake is.]

In extract 13 , student $\mathrm{F}$ viewed that corrective feedback provided by the teacher is good because she can locate her mistake. It prevented her to make it again. Whereas in extract 14 , student $\mathrm{H}$ felt sad but she thought that it could tell her mistake. This finding is supported by the study from King, Schrodt \& Weisel (2009) reporting that students experience the feeling of sensitive to corrective feedback, yet they stated that it is advantageous to them.

\section{Extract 15: Feeling happy to descriptive feedback}

A short comment was noted by student $\mathrm{D}$ about descriptive feedback.

Saya senang karena saya bisa mengetahui apa kekurangan saya dan apa yang telah saya capai selama belajar bahasa inggris. [I am happy because I can know what is my weakness and what I have achieved during I study English.]

In extract 15 , student felt happy when the teacher provided descriptive feedback to him because he could recognize his weakness and achievement during studying English. Gamlem \& Smith's study (2013) also found that descriptive feedback has high appreciation from the students' view because it can inform them their attainment and teacher's suggestion for improvement.

\section{Extract 16: Communication between the teacher and students}

Student K stated his perception of teacher's interactional feedback.

Bapak itu memberikan komentar terus artinya saling komunikasi dua arah artinya adalah menurut saya juga bagus. Kan pembelajaran di kelas bisa lebih aktif. Kemudian tidak kaku juga dalam kelas. [The teacher gives us comment meaning that there is an exchange of communication into two sides. I think it is good. The learning process in the class can be more active. Then, it is not also awkward in the class.]

\section{Extract 17: Feeling brave}

Student B conveyed his perception of motivational feedback. He said: 
Tentu termotivasi. Menjadi lebih berani untuk menjawab. Menjadi lebih tidak takut salah. [Of course, feeling motivated. We become braver to answer. We are not too afraid to make mistake.]

In extract 17 , student $\mathrm{K}$ said that interactional feedback can build the students' active participation in EFL classroom. Anyhow, the class is not awkward. In extract 18, student $\mathrm{B}$ was brave to give the answer and not afraid to make mistake after getting motivational feedback. Cullen's study (2002) contended that interactional feedback has a crucial role to create meaningful interaction between the teacher and students. Then, Mackiewicz \& Thompson's study (2013) found that providing motivational statement can increase students' confidence and encourage their persistence.

The findings of students' perceptions of interactional feedback and motivational feedback are the novelty of this study. Studies from Mackey, Gass \& McDonough (2000) and Lorincz (2014) about students' perceptions of interactional feedback focused on teachers' correction during interaction, whereas this study took emphasis on teachers' comment without evaluation or correction. Another study of motivational feedback only concerned with teachers' use of motivational feedback (Mackiewicz \& Thompson's study, 2013).

\section{CONCLUSION}

Types of oral feedback used by the teachers in EFL classroom interaction covered theories from Tunstall \& Gipps (1996), Lyster \& Ranta (1997), Cullen (2002), and Mackiewicz \& Thompson (2013), namely evaluative feedback, corrective feedback, descriptive feedback, interactional feedback, and motivational feedback. The teachers used five ways of oral feedback in EFL classroom interaction, namely providing evaluative statements to students' work or performance, indicating and correcting students' errors explicitly or implicitly, informing students' achievement and the improvement strategies of learning, clarifying and embellishing some ideas on students' responses, and providing motivational statements. There were two new ways of oral feedback found in this research. They were praise and correction in corrective feedback and giving help in motivational feedback. Then, some ways of teachers' oral feedback found have not been mentioned and discussed yet in the theory. They were questioning and giving help in interactional feedback as well as expectancy in motivational feedback. These ways completed the theory. The teachers employed oral feedback because it was their responsibility and obligation to provide it to students. It was also contemplated as the effective and efficient feedback mode. Since it had benefit and positive effect to students, the teachers applied it. The consequence of none of oral feedback was also considered by them. Mostly, students perceived positively to teachers' oral feedback based on its function and effect to them. Although some students perceived that oral feedback caused a sensitive dimension, they still realized to its positive effect to improve their achievement.

\section{REFERENCES}

Acheson, K. A., \& Gall, M. D. 1980. Techniques in the Clinical Supervision of Teachers: Perspectives and In-service Applications. New York: Longman. 
Al-Fahdi, H. M. 2006. English Language Teachers' Use of Oral Feedback. In S. Borg (Ed.), Classroom Research in English Language Teaching in Oman. Sultanate of Oman: Ministry of Education.

Black, P. \& William, D. 1998. Assessment and Classroom Learning. Assessment in Education: Principles, Policy \& Practice, 5(1), 7-74.

Brookhart, S. M. 2008. How to Give Effective Feedback to Your Students. USA: ASCD.

Cowie, B. 2005. Pupil Commentary on Assessment for Learning. The Curriculum Journal, 16(2), 137-151.

Cullen, R. 2002. Supportive Teacher Talk: The Importance of the F-Move. ELT Journal, 56(2), 117-127.

Ellis, R. 2006. Researching the Effects of Form-Focussed Instruction on L2 Acquisition. AILA Review, 19(1), 18-41.

Ellis, R. 2009. Corrective Feedback and Teacher Development. L2 Journal, 1(1), 3-18.

Gamlem, S. M. \& Smith, K. 2013. Student Perceptions of Classroom Feedback. Assessment in Education: Principles, Policy \& Practice, 20(2), 150-169.

Garcia, A. L. 2005. The Effect of Teacher Feedback on EFL Learners' Functional Production in Classroom Discourse, (Online), (http://www.uv.es/anglogermanica/2005/llinares.pdf, Accessed on $9^{\text {th }}$ August 2016).

Hargreaves, E., McCallum, B. \& Gipps, C. 2000. Teacher Feedback Strategies in Primary Classrooms-New Evidence. In S. w (Ed.), Feedback for Learning. London: RoutledgeFalmer.

Hattie, J. \& Timperley, H. 2007. The Power of Feedback. Review of Educational Research, 77(1), 81-112.

Ikeda, N. 2010. An Investigation of Teacher's Oral Feedback Move: Elaboration on Long's Model of the Decision Making Process. Sophia TESOL, 3.

King, P. E., Schrodt, P. \& Weisel, J. J. 2009. The Instructional Feedback Orientation Scale: Conceptualizing and Validating a New Measure for Assessing Perceptions of Instructional Feedback. Communication Education, 58(2), 235-261.

Kluger, A. N. \& DeNisi, A. 1996. The Effects of Feedback Interventions on Performance: A Historical Review, a Meta-Analysis, and a Preliminary Feedback Intervention Theory. Psychological Bulleting, 119(2), 254-284.

Lee, 1. 2008. Student Reactions to Teacher Feedback in Two Hong Kong Secondary Classrooms. Journal of Second Language Writing, 17(3), 144-164. 
Lorincz, K. 2014. L2 Learner Perceptions of Interactional Feedback. Linguistic Portfolios, 3(10), 98-124.

Lyster, R. \& Ranta, L. 1997. Corrective Feedback and Learner Uptake: Negotiation of Form in Communicative Classrooms. Studies in Second Language Acquisition, 19(1), 37-66.

Mackey, A., Gass, S. \& McDonough, K. 2000. How Do Learners Perceive Interactional Feedback. Studies in Second Language Acquisition, 22(4), 471-497.

Mackiewicz, J. \& Thompson, I. 2013. Motivational Scaffolding, Politeness, and Writing Center Tutoring. The Writing Center Journal, 33(1), 38-73.

Maolida, E. H. 2013. A Descriptive Study of Teacher's Oral Feedback in an ESL Young Learner Classroom in Indonesia. $k @ t a, 15(2), 117-124$.

Miles, M. B., Huberman, A. M. \& Saldaña, J. 2014. Qualitative Data Analysis: A Methods Sourcebook (3 ed.). USA: Sage Publications, Inc.

Noor, N. M., Aman, I., Mustaffa, R. \& Seong, T. K., 2010. Teacher's Verbal Feedback on Students' Response: A Malaysian ESL Classroom Discourse Analysis. ProcediaSocial and Behavioral Sciences, 7(C), 398-405.

Permatasari, V. 2016. Corrective Feedback as a Device to Remedy Students' Mispronunciation: A Case Study with Interpersonal Communication Perspective. Unpublished Thesis. Makassar: State University of Makassar.

Pfanner, N. I. 2015. Teacher Corrective Oral Feedback in the Classroom. Journal of Language and Education, 1(2). 46-55.

Pinto, J. \& Santos, L. 2008. The Teacher's Oral feedback and Learning. Paper presented at the International Congress on Mathematical Education, Mexico, $6^{\text {th }}-3^{\text {rd }}$ July.

Ran, Q. \& Danli, L. 2016. Teachers' Feedback on Students' Performance in a Secondary EFL Classroom. Proceedings of ClaSIC (242-254). Singapore: NUC Centre.

Sinclair, J. \& Coulthard, M. 1975. Towards an Analysis of Discourse: The English Used by Teachers and Pupils. Oxford: Oxford University Press.

Syam, A. 2015. English Teachers' Use of Corrective Feedback and the Effect on Students' Uptake at Senior Secondary School Level in Indonesian Context. Unpublished Thesis. Makassar: State University of Makassar.

Tharawoot, Y. 2010. Analysis of Teacher Verbal Feedback in a Thai Postgraduate Classroom, (Online), (http://eprints.soton.ac.uk/696521/1/Yaoware_Tharawoot_23_11_09.pdf, Accessed on $9^{\text {th }}$ August 2016).

Tunstall, P. \& Gipps, C. 1996. Teacher Feedback to Young Children in Formative Assessment: A Typology. British Educational Research Journal, 22(4), 389-404. 


\section{2}

ELT Worldwide Vol. 4 No. 2 (2017)

Irawan \& Salija: Teachers' Oral Feedback in Classroom ...

Voerman, L., Meijer, P. C., Korthage, F. A. J. \& Simons, R. J. 2012. Types and Frequencies of Feedback Interventions in Classroom Interaction in Secondary Education. Teaching and Teacher Education, 28(8), 1107-1115. 